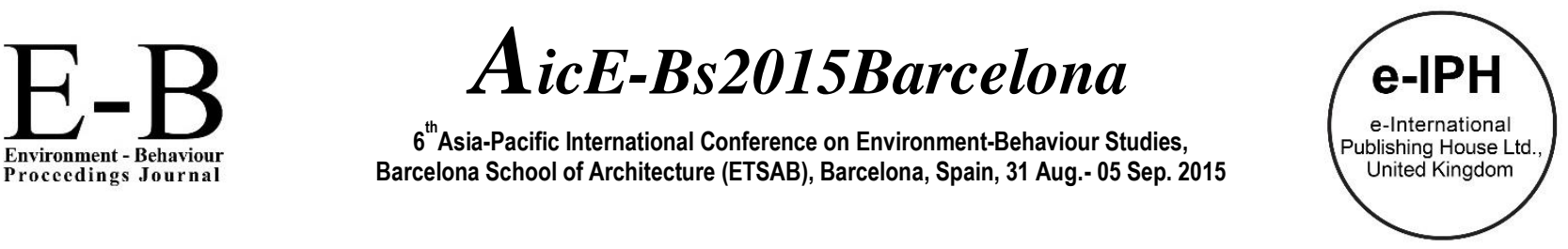

\title{
Financing Preference Behaviour for Private Finance Initiative (PFI) Projects
}

\author{
Yati Md Lasa*, Norizan Ahmad, Roshana Takim \\ Faculty of Architecture, Planning and Surveying, Universiti Teknologi MARA (UiTM) Shah Alam, 40450 Selangor, Malaysia
}

\begin{abstract}
Project Financing Initiative (PFI) projects require the private sector to invest an enormous amount of capital for the development of public projects. The private sector has to seek cost-effective financing sources for their survival in the long-term concession. Conventional financing uses widely; however, Islamic financing promises better financing through profit and loss sharing. This paper reviews financing preferences for PFI projects and the factors influencing the choice of funding. The results show that religious perspective, quality of services, financing facilities and reputation are the factors that are expected will influence the financing preference behaviour, either Islamic or conventional finance.
\end{abstract}

(c) 2016. The Authors. Published for AMER ABRA by e-International Publishing House, Ltd., UK. Peer-review under responsibility of AMER (Association of Malaysian Environment-Behaviour Researchers), ABRA (Association of Behavioural Researchers on Asians) and cE-Bs (Centre for Environment-Behaviour Studies, Faculty of Architecture, Planning \& Surveying, Universiti Teknologi MARA, Malaysia.

Keywords: Conventional project finance; Islamic project finance; preference; Private Finance Initiative

\section{Introduction}

In recent years, Private Finance Initiative (PFI) approach was used worldwide as an innovative way for the development of public facilities that help to reduce government spending. In contrast to the conventional procurement of public projects, PFI requires engagement with private sector collaboration to finance the project, as well as to undertake an integrated package of design, construct, maintain and operate the asset developed. The venture involves an agreed long-term concession, typically 2530 years (Wang, 2014). A tremendous amount of upfront investment is crucial in PFI, particularly during the construction phase (Engel et al., 2010). The private sector handles obtaining the financing necessary for the development of PFI projects. Therefore, Special Purpose Vehicle (SPV), which is the private contractor of PFI, is legally established as a responsible entity for the implementation of PFI project (Damnjanovic \& Vajdic, 2012). Conventionally, the combination of debt and equity is used to finance PFI project (Abdullah et al., 2014). However, there are other available finance sources that could be obtained from various sources, including initial public offering, senior debt, bonds, equity, mezzanine finance and grants (UN ESCAP, 2011; Gatti, 2013). In Malaysia, Abdullah et al. (2014) indicated that bank debt used approximately $80 \%$ to $90 \%$ of the funding for the PFI projects and the remaining cost of capital is financed internally through SPV's investment. There is no contribution from shareholders' equity. The said financing options usually impose higher borrowing cost, and this would affect the total project cost

\footnotetext{
${ }^{*}$ Corresponding author. Tel.: +6-019-239-5100; fax: +6-03-5544-4353.

E-mail address: yati_angah@yahoo.com
}

(C) 2016. The Authors. Published for AMER ABRA by e-International Publishing House, Ltd., UK. Peer-review under responsibility of AMER (Association of Malaysian Environment-Behaviour Researchers), ABRA (Association of Behavioural Researchers on Asians) and cE-Bs (Centre for EnvironmentBehaviour Studies, Faculty of Architecture, Planning \& Surveying, Universiti Teknologi MARA, Malaysia. 
and cash flows (UN ESCAP, 2011). Similarly, (Martín et al., 2014) found that by using private financing, the cost of infrastructure project tends to be more expensive compared to using public funding. Hence, the high cost of capital applicable under PFI makes the scheme difficult in achieving value for money (HM Treasury, 2012). HM Treasury (2012) also stressed a need for such financing that is ready to absorb risks. Therefore, there is an option for PFI players to seek cheaper financing sources and competitive for their survival in the long duration of PFI projects (Zawawi et al., 2014). The private sector should determine a target capital structure that is sufficient to the PFI project development. The capital structure will incorporate the consideration of costs and benefit of debt and equity (Chiang et al., 2011). On the other hand, Islamic project finance claimed that it holds a better promise for PFI projects financing using profits and loss sharing (Zawawi et al., 2014). Islamic project financing provides an alternative to SPV in choosing their competitive investment for their PFI projects.

Preference is a function of choice that is frequent in the lifetime phenomenon (Zinas \& Mohd Jusan, 2010). Every person, firm or organisation needs to make choices in various fields in daily operations. In PFI project financing, the behaviour of SPV in financing preferences and choices is essential, which would affect the future profit and cash flow. As highlighted by Danso \& Adomako (2014), financial resources play a significant role in an organisation's operation, in which any wrong financing decision could affect their future survival. The aim of SPV when devising a funding plan is to obtain the capital necessary to complete the project at the lowest cost and to maximise the return on the capital invested. In Malaysia, SPV has an option either to use conventional project finance or Islamic project finance for financing their PFI project. Hence, the objective of this study is to review financing preferences for PFI projects and the factors influencing the choice of those financing.

\section{Research Methodology}

A literature review was conducted on publish and non-publish articles between the year 2011 to 2015 focused on the current practice of financing preferences for PFI projects. The study identifies factors influencing choices in financing in a broad scope. These include conventional and Islamic banking and project financing. The reason for undertaking literature review as the primary methodology for the study is to establish the depth and breadth of the current state of funding knowledge in the area of project financing, especially in the respect to financing preferences in PFI project. A general awareness of available project funding option is essential to understand the difference between Islamic and conventional financing. The paper then attempts to explore the factors that are important in influencing the project financing decision making, either conventional or Islamic. The common factors were categorised and tabulated accordingly. The literature review indicates that there are four groups of factors that are influencing the choice of the financing are religious perspective, financing facilities, quality of services and reputation of the financing provider.

\section{Literature Review}

\subsection{Financing for PFI}

$\mathrm{PFI}$ scheme is an alternative way of financing public infrastructure development without direct recourse from the government budget (Chinyio \& Gameson, 2009). A substantial component of funds required for a PFI project is typically obtained through project finance (Gatti, 2013). Project finance is money and resources that are provided for the project with an expectation that the party providing the funding will receive a return on their investment that is commensurate with the risks undertaken (Duffield \& Clifton, 2009). Project finance refers to the means of financing the development of a stand-alone project on a non-recourse or limited recourse finance structure. According to Gatti (2013), the priority of project finance for PFI does not depend on the soundness and creditworthiness of the SPV. Approval does not even depend on the value of assets that SPVs are willing to make available to the financier as collateral. Instead, it is a function of the project's ability to repay the debt contracted and remunerate capital invested at a rate consistent with the degree of risk inherent in the venture concerned. In project finance, lenders and investors rely either exclusively ("non-recourse" financing) or mainly ("limited recourse" financing) on the cash flow generated by the project to repay their loans and earn a return on their investments (EPEC, 2011). In contrast to corporate finance, the lender does not consider the overall financial strength or balance sheet of the sponsor as a prerequisite to lending for a project, but primarily rely on the revenue stream generated by the project itself (Daube et al., 2008). The debt and equity used to finance the project are paid back from the cash flows generated by the project (Gatti, 2013). 
Figure 1 shows typical PFI financing structure. It shows a contractual relationship between public authority, equity sponsor, Special Purpose Vehicle (SPV), debt provider and related payment streams. Through SPV, the private contractor could limit their liability and exposure to risk in which the project's financial performance solely becomes SPV's responsibility. SPV is a legal entity that will function as the borrower under the underlying financing agreements, as well as contracted with other projectrelated contracts. The lender has to be confident with the project's viability to cover the interest and debt repayment. PFI procurement is designed with the private sector to finance the capital costs of the projects, which are paid back by the public sector.

Fig. 1. Typical PFI structure. Source: Daube et al.(2008)

\section{According to}

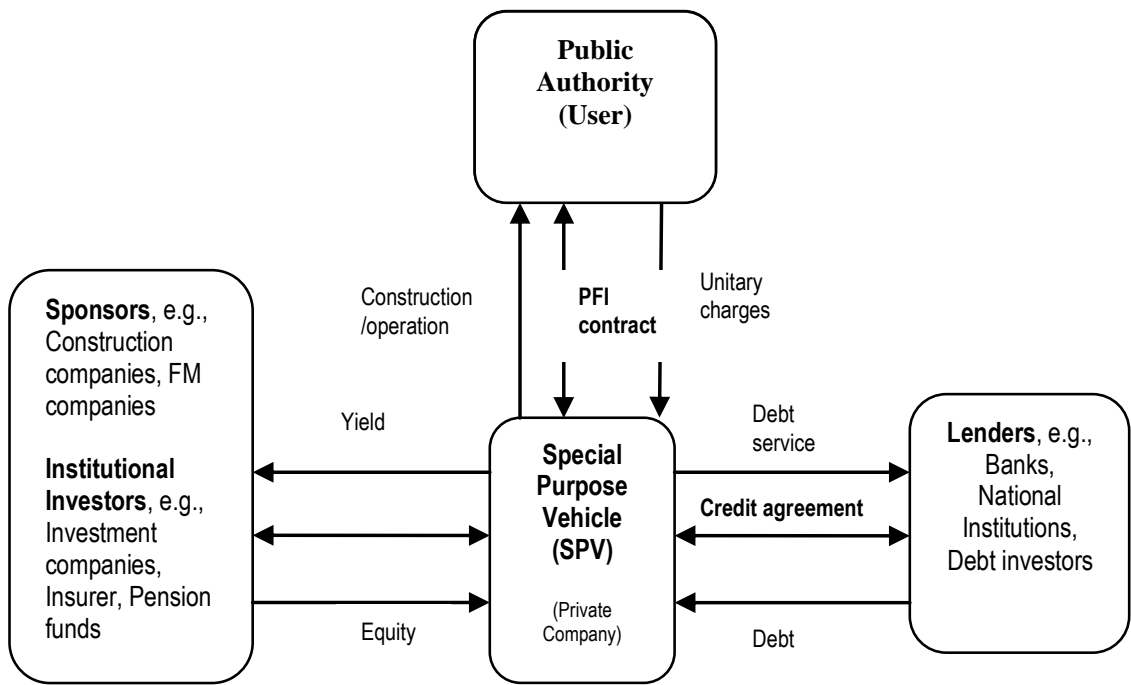

financing Adapted from

during the PFI proposal evaluation, the public authority has to assess the bankability of the proposed project contract. They should also realise the project financing arrangements and their consequences. Bankability contract will ensure the SPV to get cost-effective financing packages. Consequently, the SPV could reach affordable debt-to-equity ratio that prevents from the risk of a loan default if there is more debt in a project. The financiers have to take an incentivize to protect their investment by ensuring any project risks are addressed in order. Table 1 lists the range of conventional finance options.

Table 1. Options for conventional financing

\begin{tabular}{|c|c|c|c|}
\hline Investment & Typical appetite for risk & Description & Examples of providers \\
\hline Equity & $\begin{array}{l}\text { Fully exposed to risk - high } \\
\text { return expected }\end{array}$ & $\begin{array}{l}\text { The proprietor's capital investment in } \\
\text { an enterprise or undertaking. It is } \\
\text { unsecured, high risk and illiquid if } \\
\text { securities in the enterprise are unlisted }\end{array}$ & $\begin{array}{l}\text { Investor, major companies, } \\
\text { passive investment via } \\
\text { superannuation funds, trade } \\
\text { investors }\end{array}$ \\
\hline $\begin{array}{l}\text { Initial public offering } \\
\text { (IPO) }\end{array}$ & $\begin{array}{l}\text { Subject to the scrutiny of } \\
\text { market researchers and the } \\
\text { vagaries of the stock market }\end{array}$ & $\begin{array}{l}\text { Public raising funds through the } \\
\text { sharing of ownership }\end{array}$ & The investment markets \\
\hline Senior debt & $\begin{array}{l}\text { The highest ranking for } \\
\text { repayment, security, or } \\
\text { action, i.e. lowest risk } \\
\text { exposure }\end{array}$ & Bonds market, loan accounts & $\begin{array}{l}\text { Banks, superannuation funds and } \\
\text { capital markets }\end{array}$ \\
\hline $\begin{array}{l}\text { Mezzanine finance, } \\
\text { sometimes referred } \\
\text { to as non (or limited) } \\
\text { recourse finance }\end{array}$ & $\begin{array}{l}\text { High risk and entirely } \\
\text { dependent on the success of } \\
\text { a project }\end{array}$ & $\begin{array}{l}\text { Lenders rely on the project's cash } \\
\text { flows and security over the project } \\
\text { vehicle's assets as the only means to } \\
\text { repay debt service }\end{array}$ & $\begin{array}{l}\text { High risk and entirely dependent } \\
\text { on the success of a project }\end{array}$ \\
\hline Bonds & Risk profile ranges & Bonds are typically long-term (greater & Banks, governments and capital \\
\hline
\end{tabular}


Md Lasa, Y., et. al. / $6^{\text {th }}$ AicE-Bs2015Barcelona, Spain, 30 Aug.- 04 Sep. 2015 / E-BPJ, Maiden Issue, 1(1) June 2016 (pp.11-20)

depending on the terms and styles of the agreement

Hybrid instruments:

Debt/equity
These instruments are high risk and they are designed to maximise taxation efficiency and thus may influence the financial arrangement than one year) short term, and potentially junk bonds ( $a$ form of speculative investment)

A capital raising device that has both features of debt and equity markets

These include classes of preference shares, convertible notes, capital protected equity loans, profit participating loans, perpetual debt, endowment warrants

Source: (Duffield \& Clifton, 2009)

In Malaysia, by June 2015, there are 61 licenced banking institutions under Bank Negara Malaysia. There are 27 commercial banks, 16 Islamic banks, four international Islamic banks, 12 investment banks and two other financial institutions (BNM, 2015). It is interesting to highlight that conventional banks like HSBC, Citibank and others have also introduced a window for Islamic Banking to utilise Islamic financial products and give services to their Muslim clients and to non-Muslims who are interested in Islamic banking. However, it is surprising that only two main financial institutions are involved in offering finance to the PFI projects in Malaysia (Abdullah et al., 2014). Other commercial banks are reluctant to participate in PFI investment as they could not provide a long-term loan for a project more than ten years. According to Wang (2014), methods of statistical analysis are rarely used in the research of PFI financing issues due to the difficulty of obtaining data. Private parties declined to disclose financial data, which is an impediment to conducting research on financing issues.

\subsection{Islamic project finance}

Islamic finance has been introduced over the last few decades and has been growing very fast in all over the world, particularly in Islamic countries like Malaysia, Indonesia, Pakistan, and Middle Eastern countries. Currently, there are more than 300 Islamic financial institutions worldwide (Khediri et al., 2015). Islamic finance refers to financing activities that comply with Islamic or Sharia law known as fiqh muamalat (Islamic rules on a transaction). Sharia law, which is the sources of rules and regulations, are from the Holy Quran and the Sunnah of the Holy Prophet (Peace be upon Him), as well as other secondary sources of Islamic law such as the consensus of the ummah (ijma), analogy (qiyas) and personal reasoning (ijtihad) (Huda, 2012; Khediri et al., 2015; Javed \& Fida, 2015). Khediri et al. (2015) discovered that the five principles of the rule of Islamic finance and make Islamic finance differs from conventional or "Western finance" are as follows:

- Profit and loss sharing (PLS) where the financiers and the customers share the risks.

- All transactions have to be backed by a real economic transaction that involves a tangible asset.

- The prohibition (haram) of interest (riba). Interest (riba) free financing is claimed to be a crucial element of Islamic financing.

Riba is a premium that the borrower has to pay to the financier along with the principal amount.

- The prohibition of gharar (excessive uncertainty or speculation) and maysir (games of chance or gambling).

- The prohibition on financing for business activities that do not comply with Sharia, for instance business related to food

(alcohol, pork, tobacco), gambling (casinos, lottery schemes), entertainment (video, magazines), immoral and illicit trades (prostitution, drugs).

Islamic financing is categorised into two; Sharia-based transactions and Sharia-compliant products (Hanif, 2011) as described in Table 2. Under Sharia-based transactions, the modes of financing returns of the financier are not fixed in advance; rather, it depends upon the outcome of the project. Conversely, the loss is to be shared according to capital contribution. Thus, the significant difference between conventional and Islamic financing is Sharia compliance-based modes of financing (Hanif, 2011). 
Table 2. Categories of Islamic modes of financing

\begin{tabular}{ll}
\hline Category & Description \\
\hline $\begin{array}{l}\text { Sharia-based Transactions Product: based on the principles of risk and profit-sharing } \\
\text { Musharakah }\end{array}$ & full equity partnership or partnership financing \\
Mudarabah & partial-equity partnership or profit- sharing \\
\hline $\begin{array}{l}\text { Syariah Compliance: return of financier is predictable, predetermined and fixed within Sharia } \\
\text { Murabahah }\end{array}$ & cost-plus profit sale contract or a markup financing or limited liability \\
ljarah & rental contract or a leasing agreement \\
Musharakah & housing finance \\
Bai Salam & sale contract where price is paid in advance, goods are delivered in the future \\
Bai Bithaman Ajil & credit sales or acquisition of assets and hire purchase financing \\
Istisna & acquisition of goods by a specification, where price is paid in advance, and goods are delivered in the \\
& future \\
\hline
\end{tabular}

Source: (Hanif, 2011; Zawawi et al., 2014)

Islamic project finance is a consideration of financing acceptable projects that are in compliant with the Sharia law. According to Zawawi et al. (2014), there are various forms of Islamic project financing that can be selected for PFI. However, suitable Islamic project finance instruments depend on the types of project, project phases, Islamic law compliant and project risks. Zawawi et al., (2014) added that Bai Bithaman Ajil, ljarah and Istisna are the financing instruments option that the project company can use in the contract construction stage. These financing instruments can be used where the Islamic financier signs a contract with the project company to provide the facilities to the company on time and at an agreed price, and the financier would repay on a deferred basis.

Ismail (2013) found that Sukuk is an efficient Islamic instrument in project financing. The findings show that there are many benefits when using Islamic project finance instruments via Sukuk. The findings are as follows: (i) originators received benefit from lower cost of funds due to higher rating through the credit enhancement; could access the capital markets via transformation of illiquid assets into liquid and tradable capital market instruments; off-balance sheet finance helps to improve financial ratios as it removes both assets and liabilities from the balance sheet. (ii) Investors benefited from the Sukuk, which is typically rated higher. Thus, Sukuk provides investors with a safe harbour investment. (iii) Capital market benefits from the establishment of secondary securitization markets for benchmark purposes; facilitates and promotes an efficient allocation of capital and reduction of risks within the banking system.

A study by Zawawi et al. (2014) also found that Islamic project finance offers better promise for the financing of PFI projects. Instead of the financing scheme that is interest-free, it also provides profits and losses sharing. For that reason, it could enhance the value for money and making PFI projects development cheaper due to the absence of cost of capital. In Malaysia, among the projects that were funded by Islamic project finance include Putra LRT II project and Kuala Lumpur International Airport (Zawawi et al., 2014). In another study, Abdullah et al. (2014) revealed that in Malaysia, although the Malaysian government encourages the use of Islamic financing in funding PFI projects, but SPV could decide the methods of financing that they prefer. Abdullah et al., (2014) discovered that Islamic financing instruments suitable for PFI projects are ijarah, musyarakah and murabahah Sukuk. This Sukuk is an Islamic bond as a mode of financing that is granted based on the nature of project available for Shariacompliant contracts. Under Sukuk, shareholders including the financier and the company will share gain from the contract profits and assets. Both of them will also share the risks and responsibilities. However, the relevant type of Sukuk to be used is determined by the nature of the project.

\subsection{Underpinning theories in financing behaviour}

Financing behaviour is related to the individual, as well as the corporate level in their financing decision whether in borrowing, savings or investment decisions (Jurevičienè et al., 2014). Previous studies used the theory of Modigliani and Miller (1958) for corporate financing behaviour (Bikas et al., 2013; Danso \& Adomako, 2014; Jurevičienè et al., 2014; Irimia-Diéguez et al., 2014). 
Modigliani and Miller's theory explains that the market value of the corporation is in its ability to earn income and risk of the underlying assets. They are free to choose how to finance its investments or distribute its profits, whether by issuing shares, loans or benefits expense. The basic idea of this theory is the assumption that there is no difference whether corporate finance themselves with debt or equity based on assumptions of no taxes, no transaction cost, debt being risk free and a perfect market.

According to Guzavicius et al. (2014), when making decisions under conditions of uncertainty and risk, people will suffer the effects of different illusions, emotions, creating a false perception of information and irrational actions. Guzavicius et al. (2014) added that in the study of behavioural finance, it needs to examine the influence of social, cognitive, and emotional factors on the economic decisions of individuals and corporate, as well as the benefits of the resources that have been allocated. They also recommend that to understand better financial behaviour, other behavioural theories should be applied such as the theory of psychology, sociology, and anthropology. Behavioural finance does not just focus on the characteristics of decision-makers, but it also involves economic and social-environmental factors. Usually, an individual just follows the current norms or trying to prevent from risk and problem.

PFI has a unique characteristic comprises project finance, in which its financial structure matters and investment decisions cannot be separated from funding decisions (Irimia-Diéguez et al., 2014). For the purpose of this study, another three theories are adopted as the fundamental of research. First, the theory of the agency, proposed by Jensen \& Meckling (1976) and Myers (1977), which states the theory studies of organisational problems in which agency costs arise from the conflict between shareholders and lenders. Agency problems may arise between shareholders and the management team when defining the financial structure since managers may make the funding decisions. Agency conflict also occurs between equity holders (owners) and managers caused by asymmetry information. Asymmetry information occurs when one party has more information than the others, which makes them act in their interests. Second, the theory of hierarchical preferences, as proposed by Myers (1984) and Myers \& Majluf (1984), posits that companies do not seek to adjust to an optimal debt ratio, but due to asymmetric information problems associated with external financing, companies change their funding decisions to a hierarchy, i.e. they prefer internal to external financing and only if internal funds are insufficient, they resort to external resources.. Third, the planned behavioural theory, which was originally called the theory of reasoned action (Ajzen \& Fishbein, 1980). The theory explains a person's behaviour is on his intention, whereby people action rationally based on available information, guided by motives and know the implications of their action.

\section{Findings}

\subsection{Financing preference}

Recent researchers have investigated the differences and similarities between Islamic and conventional banks on the aspects of performance, profitability, efficiency and risk (Hanif, 2011; Huda, 2012; Ismail, 2013; Khalid, 2014; Zawawi et al., 2014; Bilal \& Abbas, 2015; Khediri et al., 2015; Javed \& Fida, 2015). In addition, studies on customer satisfaction and factors influencing the choices of either Islamic or conventional financing have also been carried out (Saad, 2012; Quresh et al., 2012; Echchabi \& Olaniyi, 2012; Ali et al., 2013; Riaz et al., 2014). As an example Quresh et al. (2012) examined the selection criteria of Islamic bank in Malaysia. The study identified service quality, and convenience were the primary criterion of consumers' preferences for Islamic banking. In contrast, Riaz et al. (2014) investigated the customer satisfaction between Islamic and conventional banks. Their findings reveal that clients of conventional banks were more satisfied than the customers of Islamic banks with the facilities provided by the banks.

According to Javed \& Fida (2015), conventional and Islamic finance have realistic differences in terms of their origin and the underlying law. The concept of Islamic and conventional financing was differentiated as the conventional financing have interest based ideology. While Islamic financing has interest free system and sharing their profit and loss with the customer (Ali et al., 2013). In practical, the only thing that distinguishes Islamic financing products from conventional financing products is riba (Ali et al., 2013). Also, Islamic finance is based on some prohibitions from any trading of haram goods. Nevertheless, Ali et al. (2013) revealed that the customers in Pakistan satisfied and preferred conventional banking because the type of facilities offered by conventional banking more variety than Islamic banking.

Previous studies contribute useful insights in examining individual customers' and business firms' behaviour towards financing preference and focus on products and services provided by the bank (Saad, 2012; Quresh et al., 2012; Echchabi \& Olaniyi, 2012; Ali et al., 2013; Riaz et al., 2014). The behaviour of customers towards financing preference to choose Islamic or 
conventional were influenced by several factors. For instance quality of services, financing products offered, religious perception, financial benefits, financiers' reputation and technology used. However, none of the studies had examined SPV behaviour in choosing project financing preferences for their PFI project investment. The novelty of this study is it attempts to identify the project financing preferences and influential factors in choosing financing methods, either Islamic project financing or conventional project financing for PFI, particularly in Malaysia. Nevertheless, in the Malaysian context, particularly in financing PFI project, studies on financing preferences are still limited.

\subsection{Influential factors in financing}

Based on literature review, this study tried to group the influencing factors, according to the same characteristics and concepts. Table 3 summarises previous researches on influential factors towards conventional and Islamic financing for the period of 2011-2015. Detailed discussion related to the common factors as follows.

Table 3. Summary of previous researches on influential factors towards conventional and Islamic financing

\begin{tabular}{|c|c|c|c|c|c|}
\hline No & Author & $\begin{array}{l}\text { Factor } \\
\text { group }\end{array}$ & Influential factors & $\begin{array}{l}\text { Islamic } \\
\text { Financing/ } \\
\text { Banking }\end{array}$ & $\begin{array}{l}\text { Conventional } \\
\text { Financing/ } \\
\text { Banking }\end{array}$ \\
\hline 1 & $\begin{array}{l}\text { Hanif (2011); Quresh et al. (2012); Echchabi \& } \\
\text { Olaniyi (2012); Riaz et al. (2014) and Bilal \& Abbas } \\
\text { (2015) }\end{array}$ & $\begin{array}{l}\text { Religious } \\
\text { perspective }\end{array}$ & $\begin{array}{l}\text { Run on Islamic law and } \\
\text { principles }\end{array}$ & $\checkmark$ & - \\
\hline 2 & Saad (2012) and Echchabi \& Olaniyi (2012) & \multirow{7}{*}{$\begin{array}{l}\text { Quality of } \\
\text { Services }\end{array}$} & Courteous & $\checkmark$ & - \\
\hline 3 & Saad (2012) and Echchabi \& Olaniyi (2012); & & Competency & $\checkmark$ & $\checkmark$ \\
\hline 4 & Saad (2012) and Quresh et al. (2012) & & Ethical & $\checkmark$ & $\checkmark$ \\
\hline 5 & Saad (2012) and Echchabi \& Olaniyi (2012) & & Efficiency of transaction & $\checkmark$ & $\checkmark$ \\
\hline 6 & Saad (2012) & & Physical facilities provided & - & $\checkmark$ \\
\hline 7 & Quresh et al. (2012) and Echchabi \& Olaniyi (2012) & & Convenience & $\checkmark$ & $\checkmark$ \\
\hline 8 & Quresh et al. (2012) & & Technology & - & $\checkmark$ \\
\hline 9 & Hanif (2011), Ali et al. (2013) and Riaz et al. (2014) & \multirow{9}{*}{$\begin{array}{l}\text { Financing } \\
\text { facilities }\end{array}$} & Investment options & - & $\checkmark$ \\
\hline 10 & Hanif (2011), Ali et al. (2013) and Riaz et al., (2014) & & Financing options & - & $\checkmark$ \\
\hline 11 & Quresh et al. (2012) & & $\begin{array}{l}\text { Transparency in } \\
\text { transactions }\end{array}$ & $\checkmark$ & - \\
\hline 12 & Quresh et al. (2012) and Rod (2015) & & Low service charge & $\checkmark$ & $\checkmark$ \\
\hline 13 & Riaz et al. (2014) & & Interest rate & - & $\checkmark$ \\
\hline 14 & Riaz et al. (2014) & & Interest-free loan & $\checkmark$ & - \\
\hline 15 & Bilal \& Abbas (2015) and Khediri et al. (2015) & & Higher rate of return & $\checkmark$ & - \\
\hline 16 & Khediri et al. (2015) & & Low credit risk & $\checkmark$ & - \\
\hline 17 & Riaz et al. (2014) & & Profit and loss sharing & $\checkmark$ & - \\
\hline 18 & $\begin{array}{l}\text { Quresh et al. (2012); Echchabi \& Olaniyi (2012); } \\
\text { Riaz et al. (2014) and Rod et al. (2015) }\end{array}$ & \multirow{3}{*}{ Reputation } & Credibility & $\checkmark$ & $\checkmark$ \\
\hline 19 & Riaz et al. (2014) & & Image & - & $\checkmark$ \\
\hline 20 & Riaz et al. (2014) & & Network & - & $\checkmark$ \\
\hline & Total Score & & & 13 & 13 \\
\hline
\end{tabular}

- Religious Perspective

Islamic aspect is one of the main differences between the conventional and Islamic financing (Echchabi \& Olaniyi, 2012). The fundamental of the Islamic system of finance is to comply a diverse set of regulations as stated in the Holy Quran (Ali et al., 2013). All financing activities must follow the Islamic Law as created and governed by Sharia and Fiqah. Sharia ban all kind of 
interest (riba) to prevent injustice, encourage work, and productive efforts, as well seek an equitable form of the transaction (Hanif, 2011). Customers in Islamic financial system could involve any transactions but they are prohibited entering in such transactions which related with riba and gharar.

Quresh et al. (2012) highlight the role of the religious motif among other important, influential factors in Islamic project financing. Alexander (2011) claimed that in the Islamic world, compliance with Sharia law has caused difficulty for Western project financiers to undertake projects. Islamic financing also refers to ethical financing that follows Sharia law when dealing with people and transactions regarding tangible activity (Quresh et al., 2012; Rod et al., 2015). Generally, knowledge of Islam or with Islamic background, understood with Islamic financing system and religious environment in the city are the factors motivating customers preferred Islamic financing (Quresh et al., 2012; Riaz et al., 2014). Furthermore, their belief in Allah (God) causes them not interested in dealing with those conventional financing institutions. As the conventional financing is based the ideology of capitalism and interest as priority, which is banned in Islam.

- Quality of services

The quality of services refers to the overall performance of provided activity that promotes customer satisfaction. The quality of services is critical for banking success because its attracts more customers and more profit (Echchabi \& Olaniyi, 2012). The quality of services includes courteous, competent, ethical of the staff, the efficiency of the transactions, physical facilities provided, convenience and technology used by the banks. These factors were influencing customers in making a decision to choose a particular bank either conventional or Islamic (Saad, 2012; Echchabi \& Olaniyi, 2012; Quresh et al., 2012).

As shown in Table 3, there are six influential factors in conventional financing. There are competent and knowledgeable of the staff, ethical behaviour of employees, speed and efficiency of the transaction, physical facilities provided, convenience and updated technology used. Compared to Islamic financing, major factors that attract the customers to choose Islamic are courteous, competent and knowledgeable of the staff, ethical behaviour of employees, speed and efficiency of transaction and convenience. Customers prefer financing institutions that could give them a quality of services (Echchabi \& Olaniyi, 2012; Saad, 2012). Nevertheless, customers who need a good service and low pricing would choose either Islamic or conventional option (Rod et al., 2015). On the other hand, a person's attitude towards choosing a bank is subjective and may also be affected by the social influence and their environment (Quresh et al., 2012).

- Financing Facilities

Financing facilities is related to the financing products and services offered by a financing institution. The literature review indicated that nine influential factors that grouped in the financing facilities that influencing financing preference. Transparency in transactions, interest-free loan, higher rate of return, low credit risk and profit and loss sharing among the factors that are motivating customers preferred Islamic financing rather than conventional financing. Investment options, financing options and interest rate are the factors that are influencing customers towards conventional financing. In other hand, low service charge is the influential factor in both financing scheme.

Customers who are looking for economical financing are looking for financiers that could provide financial benefits with low service charges such as processing fee (Quresh et al., 2012). If the customers have to choose two products, conventional and Islamic options are both at par, with no different in cost, term and rate; but now, many companies will accept Islamic financing (Rod et al., 2015). Riaz et al. (2014), reported that the factors that motivated customers in choosing Islamic financing due to economic benefits they received in the form of profit sharing and the interest-free loan.

\section{- Reputation}

Reputation refers to the credibility of the banks and their prestige among their competitors. Customers are looking for the reputation of the financial institutions when deciding financier selection (Quresh et al., 2012; Echchabi \& Olaniyi, 2012; Riaz et al., 2014). Financial institutions that have better reputation and image will have more chance to be recommended by their customers to the non-customers. Riaz et al. (2014) agreed that financing institutions with strong image and networks will be chosen among their customers. From the literature analysis is shown that customers preferred conventional financing because they have credibility, strong image and network (Quresh et al., 2012; Echchabi \& Olaniyi, 2012; Riaz et al., 2014; Rod et al., 2015).

\section{Conclusions and Recommendations}

The aim of this paper is to review financing preferences for PFI projects and the factors influencing financing preference. The issue in which SPV has to provide massive capital investment for PFI development has caused the private sector to seek cost- 
effective financing sources for their survival in the long-term concession. The unique characteristic of PFI in which its financial structure and investment decisions should be carried out with funding decisions. Hence, the behaviour of SPV in financing preferences and choices is essential, because their choice of financing method would affect the future profit and cash flow. A comprehensive literature review indicates that the PFI players have an option in their PFI project financing between conventional and Islamic project financing. Their funding preference is influencing by four main factors, including religious perspective, quality of services, financing facilities and reputation of the financing provider. It also indicates that there are different the influential factors that affected customers in choosing between Islamic financing and conventional financing. Findings from the literature review will be used to develop a questionnaire that aims to investigate financing method for PFI project and to identify its financing influential factors and derive a theoretical framework for further research. A quantitative method using questionnaire survey technique will be adopted as the research methodology. The paper makes a contribution to the PFI financing literature in providing a several important characteristics of conventional and Islamic project finance as a useful tool for SPV in giving consideration on choosing competitive project financing preferences.

\section{Acknowledgements}

The author is grateful to Public Services Department (JPA), Malaysia for financial support.

\section{References}

Abdullah, N., Sufian, A., Asenova, D., \& Bailey, S. J. (2014). PPP / PFI in Malaysian Development Plans : Purpose, structure, implementation, financing and risk transfer. In proceedings of 5th Asia-Pacific business research conference (pp. 1-14). Kuala Lumpur, Malaysia.

Ajzen, I., \& Fishbein, M. (1980). Understanding attitudes and predicting social change. New Jessey: Prentice-Hill.

Ali, L., Ali, A., \& Khwaja, H. (2013). Comparison of Islamic and conventional banking on the basis of riba and services. International review of management and business research, 2(3), 837-846.

Bikas, E., Jurevičienè, D., Dubinskas, P., \& Novickytè, L. (2013). Behavioural finance: The emergence and development trends. Procedia - social and behavioral sciences, 82, 870-876.

Bilal, M., \& Abbas, S. (2015). Comparison of Islamic banking and conventional banking: An empirical review.

Bank Negara Malaysia. (2015). (http://www.bnm.gov.my/index.php?ch=li\&cat=banking\&type=\&lang=en). Retrived on 1st July 2015.

Chiang, Y.-H., Cheng, E. W. L., \& Lam, P. T. I. (2011). A three-phase approach to construction borrowing decisions. Architectural science review, 54(3), 225231.

Damnjanovic, I., \& Vajdic, N. (2012). Roadway network externalities in project finance loan arrangements. Public works management \& policy, $17(4), 328-347$.

Danso, A., \& Adomako, S. (2014). The financing behaviour of firms and financial crisis. Managerial finance, 40(12), 1159-1174.

Daube, D., Vollrath, S., \& Alfen, H. W. (2008). A comparison of project finance and the forfeiting model as financing forms for PPP projects in Germany. International journal of project management, 26(4), 376-387. 1

Duffield, C. F., \& Clifton, C. J. (2009). Combining finance and design innovation to develop winning proposals. In policy, finance \& management for public-private partnerships edited (pp. 327-345). Blackwell Publishing Ltd.

Echchabi, A., \& Olaniyi, O. N. (2012). Malaysian consumers\&apos; preferences for Islamic banking attributes. International journal of social economics, 39(11), 859-874.

Engel, E., Fischer, R., \& Galetovic, A. (2010). The economics of infrastructure finance : Public-Private Partnerships versus public provision. European Investment Bank, 15(1), 40-70.

EPEC. (2011). The guide to guidance: How to prepare, procure and deliver PPP projects.

Gatti, S. (2013). Project finance in theory and practice: designing, structuring, and financing private and public projects. Academic Press.

Guzavicius, A., Vilkè, R., \& Barkauskas, V. (2014). Behavioural finance: Corporate social responsibility approach. Procedia - social and behavioral sciences, 156(April), 518-523.

Hanif, M. (2011). Differences and similarities in Islamic and conventional banking. International Journal of Business and Social Sciences, 2(2), 166-175.

HM Treasury. (2012). A new approach to public private partnerships. London, UK.

Huda, A. N. (2012). The development of Islamic financing scheme for SMEs in a developing country: The Indonesian case. Procedia - social and behavioral sciences, 52, 179-186.

Irimia-Diéguez, A. I., González-Villegas, J. B., \& Oliver-Alfonso, M. D. (2014). The financial performance of an innovative megaproject. Procedia - social and behavioral sciences, 119(2005), 417-426.

Ismail, A. G. (2013). Public Private Partnerships : Lesson from Sukuk. Saudi Arabia.

Javed, A., \& Fida, B. A. (2015). Islamic project financing in Pakistan : Current challenges and opportunities ahead. Iranian journal of management studies, 8(1), $47-71$.

Jensen, M., \& Meckling, W. (1976). Theory of the firm: managerial behaviour, agency costs and capital structure. Journal of financial economics, 3, pp. 305-360 
Jurevičienè, D., Bikas, E., Keliuotytè-Staniulènienè, G., Novickytè, L., \& Dubinskas, P. (2014). Assessment of corporate behavioural finance. Procedia - social and behavioral sciences, 140, 432-439.

Khalid, M. (2014). Murabahah versus interest rate , the equilibrium relationship with macroeconomic variables in Jordanian economy : An ARDL approach. Procedia - social and behavioral sciences, 129, 349-357.

Khediri, K. Ben, Charfeddine, L., \& Youssef, S. Ben. (2015). Islamic versus conventional banks in the GCC countries: A comparative study using classification techniques. Research in International Business and Finance, 33, 75-98.

Martín, L., Calvo, F., Hermoso, A., \& de Oña, J. (2014). Analysis of light rail systems in Spain according to their type of funding. Procedia - social and behavioral sciences, 162(PANAM 2014), 419-428.

Modigliani, F. \& Miller, M. (1958). The cost of capital, corporation finance, and theory of investment, American Economic Review, 48, pp. $261-297$.

Myers, S., (1984). The capital structure puzzle. Journal of finance, 34, pp.575-592.

Myers, S. \& Majluf, N. (1984). Corporate financing and investment decisions when firms have information that investors do not have. Journal of financial economics, 13, pp. 187-221.

Quresh, A. H., Hussain, Z., \& Rehman, K. U. (2012). A comparison between Islamic banking and conventional banking sector in Pakistan. Information management and business review, 4(3), 195-204.

Riaz, A., Awad, R., \& Nadia, S. (2014). Customer satisfaction between Islamic and conventional banks : Case of Pakistan. Social and basic sciences research review, 1(2), 69-73.

Rod, M., ALHussan, F. B., \& Beal, T. (2015). Conventional and Islamic banking : perspectives from Malaysian Islamic bank managers. International journal islamic marketing and branding, 1(1), 36-54.

Saad, N. M. (2012). Comparative analysis of customer satisfaction on Islamic and conventional banks in Malaysia. Asian social science, 8(1), 73-80.

UN ESCAP. (2011). A Guidebook on Public-Private Partnership in Infrastructure. Bangkok, Thailand.

Wang, N. (2014). Private finance initiative as a new way to manage public facilities. Facilities, 32(11/12), 584-605.

Zawawi, N. A. W. A., Ahmad, M., Umar, A. a., Khamidi, M. F., \& Idrus, A. (2014). Financing PF2 projects: Opportunities for Islamic project finance. Procedia engineering, 77, 179-187.

Zinas, B. Z., \& Mohd Jusan, M. (2010). Choice behaviour of housing attributes : Theory and measurement. Asian journal of environment-behaviur studies, 1(2), $1-18$. 